\title{
EVALUASI PROGRAM ROAD SAFETY PARTNERSHIP ACTION POLICE GOES TO SCHOOL DI SMA NEGERI 6 DAN SMK PEMBANGUNAN KOTA BOGOR
}

\section{ROAD SAFETY PARTNERSHIP PROGRAM EVALUATION OF POLICE ACTION GOES TO SCHOOL IN SMA 6 AND SMK PEMBANGUNAN IN BOGOR CITY}

\author{
Retno Wulandari ${ }^{1}$, Euis Salbiah ${ }^{2}$, Muhamad YGG Seran ${ }^{3}$
}

\begin{abstract}
${ }^{1}$ Jurusan Ilmu Administrasi Negara Fakultas Imu Sosial dan Ilmu Politik Universitas Djuanda, Jl.Tol Ciawi No 1, Kotak Pos 35 Bogor 16770

2 Jurusan Ilmu Administrasi Negara Fakultas Imu Sosial dan Ilmu Politik Universitas Djuanda, Jl.Tol Ciawi No 1, Kotak Pos 35 Bogor 16770

${ }^{3}$ Jurusan Ilmu Administrasi Negara Fakultas Imu Sosial dan Ilmu Politik Universitas Djuanda, Jl.Tol Ciawi No 1, Kotak Pos 35 Bogor 16770
\end{abstract}

(Diterima oleh Dewan Redaksi: 01-02-2017)

(Dipublikasikan oleh Dewan Redaksi: 01-04-2017)

\begin{abstract}
The purpose of this study is to know the Road Safety Partnership Action Program Police Goes To School at SMAN 6 and SMK Pembangunan in Bogor City.

The theory used in this research is by using policy evaluation from William N. Dunn which stating that to measure the success of an evaluation of the program can be measured through six variables: effectiveness, efficiency, adequacy, equity, responsiveness, and appropriateness. The method used is descriptive analysis using quantitative approach. Data analysis technique used is by using the calculation of Weight Mean Score (WMS). Data collection techniques used are literature studies and field studies. The study population are 1,857 students from two schools. While the sampling technique used is proportionate stratified random sampling (stratified proportional). The samples using Yamane formula thus obtained sample are 180 respondents.

The results of Program Evaluation Research Road Safety Partnership Action Police Goes To School in SMA 6 and SMK Pembangunan Bogor City obtained a score of 3.64 (in scale of 5) which, according to the interpretation of the criteria that are in "good" categories, although it is still the number of violations that occurred among students. This happens due to the lack of awareness of students in traffic, do not care about the safety and ignore the socialization conducted by the police about the ethics of a good drive to support traffic safety and reduce the number of traffic violations or accidents. Efforts are being made to address the problem is by imposing preventive methods (prevention) and applying repressive methods (in applying force).
\end{abstract}

Keywords: Evaluation, Program, Violation

\begin{abstract}
ABSTRAK
Tujuan penelitian ini adalah mengetahui Program Road Safety Partnership Action Police Goes To School Di SMA Negeri 6 Dan SMK Pembangunan Kota Bogor.

Teori yang digunakan dalam penelitian ini yaitu dengan menggunakan Evaluasi kebijakan William N. Dunn yang menyatakan bahwa untuk mengukur keberhasilan suatu evaluasi program dapat di ukur melalui enam variabel yaitu: efektifitas, efesiensi, kecukupan, pemerataan, responsivitas, ketepatan.
\end{abstract}


Metode yang digunakan adalah deskriptif analisis dengan menggunakan pendekatan Kuantitatif. Sedangkan teknik analisis data yang digunakan yaitu dengan menggunakan perhitungan Weight Mean Score (WMS). Teknik pengumpulan data yang digunakan adalah studi kepustakaan dan studi lapangan. Populasi penelitian ini berjumlah 1.857 responden dari 2 sekolah. Sedangkan teknik sampling yang digunakan adalah proportionate stratified random sampling (berstrata secara proporsional). Penentuan sampel menggunakan rumus Yamane sehingga sampel yang diperoleh adalah 180 responden.

Hasil penelitian Evaluasi Program Road Safety Partnership Action Police Goes To School Di SMA Negeri 6 dan SMK Pembangunan Kota Bogor diperoleh skor sebesar 3,64 yang menurut penafsiran kriteria berada pada kategori baik, sekalipun demikian masih banyaknya pelanggaran yang terjadi dikalangan pelajar. Hal ini terjadi dikarenakan kurangnya kesadaran pelajar dalam berlalu lintas, tidak peduli terhadap keselamatan dan menghiraukan sosialisasi yang dilakukan oleh kepolisian tentang etika berkendara yang baik untuk menunjang keselamatan berlalu lintas dan menekan angka pelanggaran atau kecelakaan lalu lintas. Upaya yang dilakukan untuk mengatasi masalah adalah dengan cara memberlakukan metode preventif (upaya pencegahan) dan menerapkan metode represif (upaya penerapan paksa).

Kata Kunci: Evaluasi Program, Pelanggaran

Retno Wulandari, 2017. Evaluasi Program Road Safety Partnership Action Police Goes to School Di SMA Negeri 6 dan SMK Pembangunan Kota Bogor. Jurnal Governansi. 


\section{PENDAHULUAN}

Pada jaman sekarang sepeda motor menjadi trend dalam pergaulan,sehingga remaja lebih mudah dipercaya oleh orang tua karena faktor lingkungan yang membuat orang tua bereaksi melihat keadaan disekitar, apa yang mendorong remaja meminta sepeda motor. Namun terkadang remaja kerap kali kurang disiplin dan salah dalam memanfaatkan kegunaan jalan, yang digunakan bukan hanya oleh pengendara kendaraan bermotor melainkan pejalan dan lain - lain.

Sehingga hal tersebut mengakibatkan munculnya fenomena lain seperti kebutkebutan yang difaktori oleh pengaruh lingkungan seperti terjadinya balapan hingga melanggar marka jalan dan rambu dijalan yang kian dapat menggangu pengguna jalan lain yang dapat mengakibatkan kecelakaan bahkan kematian.

Fenomena itu membuat remaja seakan tidak beretika dalam mengemudi. fenomena lain yaitu remaja Kota Bogor masih kurang memahami sosialisai yang telah dilakukan oleh kepolisian selain itu, sebagian dari remaja belum mendapatkan surat izin mengemudi sesuai dengan Undang-undang dasar Republik Indonesia No. 22 tahun 2009 tentang lalu lintas dan angkutan jalan dengan Perda No. 3 tahun 2013 hingga maraknya remaja yang melakukan pelanggaran.

Hal ini banyak siswa SMA di kota bogor yang melanggar aturan tata tertib lalu lintas dan kurangnya pemahaman norma berlalu lintas seperti :

a. Melanggar lampu rambu - rambu lalu lintas atau menerobos lampu merah,

b. Mengendarai motor tanpa surat izin mengemudi (sim)

c. Boncengan melebihi kapasitas

d. Tidak menggunakan helm

e. Tidak menggunakan sabuk pengaman
Oleh karena itu pemahaman norma berlalu lintas pada siswa SMA mempunyai dampak yang besar. Sesuai dengan kondisinya semakin hari semakin meningkat, hingga diperlukan suatu strategi dan langkah-langkah perbaikan system administrasi, prosedur dan mekanisme penindakan pelanggran lalu lintas jalan tertentu yang lebih efektif dan lebih baik. Hal ini diakibatkan karena kurangnya pemahaman norma hukum siswa dalam berlalu lintas.

Berdasarkan uraian di atas bahwa pemahaman norma berlalu lintas pada siswa SMA di kota bogor merupakan salah satu faktor penting dalam :

1) menyelenggarakan peraturan lalu lintas

2) pengetahuan tentang peraturan hukum

3) pengetahuan tentang isi peraturan hukum

4) sikap tentang peraturan hukum

5) pola perilaku hukum.

Merujuk kepada permasalahan lalu lintas, pemerintah telah menyusun Rencana Umum Nasional Keselamatan (RUNK) jalan tahun 2011-2035 yang bertujuan untuk memberikan pedoman bagi para pemangku kebijakan ( stake holders ) bidang lalu lintas agar dapat merencanakan dan melaksanakan penanganan keselamatan jalan secara terkoordinasi dan selaras dalam semangat kebersamaan dan menghilangkan ego sektoral.

Guna mengimplementasikan RUNK ( Rencana Umum Nasional Keselamatan jalan) tahun 2011 - 2035, Polri telah menyusun program dan aksi Polri yang merupakan pedoman, arah, kebijakan, strategi, dan program kegiatan bagi seluruh jajaran polisi lalu lintas seindonesia. Dengan tujuan untuk memberikan panduan kepada Direktorat lalu lintas Polda se Indonesia dalam merencanakan dan melaksanakan penanganan keselamatan jalan secara 
terkoordinir dan selaras serta dapat menjadi acuan dalam menjabarkan langkah-langkah penanganan keselamatan jalan di wilayah masing-masing.

Di dalam program dan rencana aksi Polri dalam RUNK (Rencana Umum Nasional Keselamatan) jalan 2011 2035 program prioritas atau program unggulan yang harus diimplementasikan oleh seluruh Direktorat lalu lintas seIndonesia yang salah satunya adalah penyelenggaraan program RSPA ( Road Safety Partnership Action ) RSPA adalah suatu program aksi kemitraan dalam mendukung keselamatan jalan. Program ini dilaksanakan sebagai tindak lanjut dari Dekade Aksi Keselamatan Jalan 2011-2020, dengan mengajak instansi yang terkait bersama dengan elemen masyarakat lainnya untuk bekerja sama menemukan problem solving dari permasalahan lalu lintas.

Adapun Program unggulan Pendidikan masyarakat dan lalu lintas ( Dikmas Lantas) dalam Road Safety Partnership Action (RSPA) meliputi :

1) Polisi Sahabat anak (PSA).

2) Patroli Keamanan Sekolah (PKS).

3) Police Goes to Campus / School.

4) Safety Riding

5) Kampanye keselamatan lalu-lintas.

6) Sekolah Mengemudi.

7) Taman lalu lintas.

8) Saka Bhayangkara.

Salah satu program dari RSPA yang akan diteliti yaitu Police Go To School yang mempunyai beberapa pelaksanaan kegiatan diantaranya :

a. Menjadi Pembina Upacara.

b. Sosialisasi Undang-undang No. 22 tahun 2009.

c. Materi Safety Riding dan etika berlalu lintas

d. Pemberian materi kamtibmas lainnya.

e. Paparan tata cara dan etika berlalulintas.

f. Sosialisasi Sim Komunitas

g. edukasi cara aman berkendara yang baik.
Program RSPA ini adalah program nasional akan tetapi di POLRESTA Bogor program RSPA dinaungi oleh Unit Dikyasa dan dilaksanakan di seluruh sekolah di kota bogor dari mulai TK, SD, SMP, SMA/SMK hingga perguruan tinggi. Peneliti hanya akan meneliti sekolah tingkat SMA/SMK dikarenakan jumlah sekolah tingkat SMA/SMK dikota bogor sekitar 131 sekolah maka peneliti hanya akan mengambil 2 sekolah sebagai perwakilan negeri dan swasta yang telah mendapatkan penyuluhan dari kepolisian mengenai program road safety partnership action dan untuk keperluan penelitian evaluasi program RSPA, adapun nama sekolah yang terpilih untuk dilakukan penelitian yaitu SMA Negeri 6 Kota Bogor dan SMK Pembangunan Kota Bogor.

Dari penjelasan dan permasalahan di atas maka peneliti tertarik untuk melakukan penelitian dalam bentuk skripsi dengan judul " Evaluasi Program Road

Safety Patnership Action Police Goes To School Di Sma Negeri 6 Dan Smk Pembangunan Kota Bogor.

\section{MATERI DAN METODE}

Menurut Sugiyono (2007:1) metode penelitian pada dasarnya merupakan cara ilmiah untuk mendapatkan data dengan tujuan dan kegunaan tertentu. Metode penelitian merupakan ilmu yang mempelajari tentang metode-metode penelitian, ilmu tentang alat-alat dalam penelitian, dilingkungan filsafat, logika dikenal sebagai ilmu tentang alat-alat untuk mencari kebenaran. Bila ditata dalam sistematika, metodologi penelitian merupakan bagian dari logika (Neong Muhadjir, 1998:140)

Menurut Sugiyono (2012:11) menjelaskan penelitian deskriptif analisis adalah penelitian yang dilakukan untuk mengetahui nilai variabel mandiri, baik satu variabel atau lebih (independen) tanpa membuat perbandingan, atau menghubungkan 
antara variabel satu dengan variabel yang lain

Teori yang digunakan oleh peneliti adalah teori dari William N. Dunn (2000:36) Evaluasi merupakan analisa terhadap sebuah fakta dan tanggapan yang dihasilkan ketika sebuah program atau kebijakan dilaksanakan. Secara umum, Dunn menggambarkan kriteria - kriteria evaluasi kebijakan sebagai berikut:

1. Efektifitas,

2. Efesiensi,

3. Kecukupan,

4. Pemerataan,

5. Responsivitas

6. Ketepatan

Metode yang digunakan pada penelitian ini adalah metode Deskriptif. Analisis. Menurut sugiyono (2012:11) adalah penelitian yang dilakukan untuk mengetahui nilai variabel mandiri, baik satu variabel atau lebih ( independen ) tanpa membuat perbandingan, atau menghubungkan antara variabel satu dengan variabel yang lain. Penelitian ini menggunakan pendekatan kuantitatif.

\section{Populasi dan Sampel}

Menurut sugiyono populasi adalah wilayah generalisasi yang terdiri atas : objek/subjek yang mempunyai kualitas dan karakteristik tertentu yang ditetapkan oleh peneliti untuk dipelajari dan kemudian ditarik kesimpulannya.

Populasi dalam penelitian ini adalah siswa/siswi SMA Negeri 6 dan SMK Pembangunan Kota Bogor yang berjumlah 1.857 orang.

Dari populasi tersebut dapat ditarik sampel. Sampel adalah bagian dari jumlah karakteristik yang dimiliki oleh populasi tersebut dan sampel yang tergolong kedalam teknik probability sampling yaitu proportionate stratified random sampling yaitu teknik sampling yang mempunyai anggota atau unsur yang tidak homogen dan berstrata secara proporsional (sugiyono,2012:93).

Selanjutnya untuk mendapatkan besaran jumlah sampel dalam penelitian ini menggunakan rumus untuk menghitung besarnya sampel yang diperlukan dalam penelitian ini adalah menggunakan rumus Yamane yang dikutip oleh Rahmat (1999:133) sebagai berikut :

$$
\begin{aligned}
& \text { Keterangan: } \mathbf{n}=\frac{\mathbf{N}}{\mathbf{N d}^{2}+\mathbf{1}} \\
& \mathrm{n} \quad \text { : Ukuran sampel } \\
& \mathrm{N} \text { : Populasi } \\
& \text { d : Tingkat kesalahan ditetapkan } \\
& \text { secara sengaja sebesar } 10 \%
\end{aligned}
$$

sumber Yamane dalam Rahmat (1999:113)

Untuk mendapatkan jumlah sampel per sub populasi dilakukan perhitungan menggunakan rumus metode alokasi proposional menurut Nazir M. (1998:365) yaitu :

$$
n i=\frac{N i}{\mathrm{~N}} \times n
$$

Dimana :

ni = ukuran sampel yang di ambil dari stratum ke-i

$\mathrm{Ni}=$ Ukuran populasi stratum ke $-\mathrm{i}$

$\mathrm{N}=$ Ukuran Populasi

$\mathrm{n}=$ Ukuran sampel yang diambil

Dengan kata lain bahwa :

$$
\begin{aligned}
& \mathrm{ni}=\text { adalah nilai sampel yang dicari } \\
& \text { dari tiap sub populasi } \\
& \mathrm{Ni}=\text { Jumlah tiap sub populasi } \\
& \mathrm{N}=893 \\
& \mathrm{n}=90
\end{aligned}
$$

Berikut perhitungan tiap populasi : 
Tabel sampel (proportionate stratified random sampling)

\begin{tabular}{|c|c|c|c|}
\hline \multirow{3}{*}{$\begin{array}{l}\text { No } \\
1\end{array}$} & \multicolumn{3}{|c|}{ Populasi Sampel } \\
\hline & \multicolumn{3}{|c|}{ Siswa SMA Negeri 6 Bogor } \\
\hline & Kelas 1 & 303 & 30 \\
\hline \multirow{9}{*}{2} & Kelas 2 & 328 & 33 \\
\hline & Kelas 3 & 262 & 27 \\
\hline & Jumlah & 893 & 90 \\
\hline & \multirow{2}{*}{\multicolumn{3}{|c|}{ Siswa SMK Pembangunan }} \\
\hline & & & \\
\hline & Kelas 1 & - & - \\
\hline & Kelas 2 & 494 & 46 \\
\hline & Kelas 3 & 470 & 44 \\
\hline & Jumlah & 964 & 90 \\
\hline
\end{tabular}

Sumber : Hasil Penelitian 2017

Dari hasil penelitian tersebut, maka jumlah sampel representative yang digunakan dalam penelitian ini adalah sebanyak 180 (seratus delapan puluh) orang pelajar.

\section{Teknik Pengumpulan Data}

Untuk memperoleh data yang diperlukan, maka penulis menggunakan beberapa teknik pengumpulan data sebagai berikut:

1. Teknik pengumpulan data primer

a. Kuesioner (angket)

Merupakan metode pengambilan data dengan menggunakan sejumlah pertanyaan tertulis yang digunakan untuk memperoleh informasi dari responden dalam arti laporan tentang pribadinya, atau hal-hal yang ia ketahui (Arikunto, 2006: 151).

b. Observasi

kegiatan mengamati secara langsung objek penelitian dengan mencatat gejalagejala yang ditemukan dilapangan untuk melengkapi data-data yang diperlukan sebagai acuan yang berkenaan dengan topik.

\section{c. Wawancara}

Peneliti menggunakan wawancara tersruktur yaitu wawancara yang terdiri dari suatu daftar pertanyaan yang telah direncanakan dan telah disusun sebelumnya. Semua responden mendapat pertanyaan yang sama, dengan kata-kata dan dalam tata urutan secara uniform

2. Teknik pengumpulan data sekunder Studi kepustakaan, yaitu pengumpulan data yang diperoleh melalui buku- buku ilmiah, tulisan, karangan ilmiah yang bekaitan dengan penelitian.

Dokumentasi

Dokumentasi yaitu dengan mengggunakan catatan- catatan yang ada dalam lokasi penelitian serta sumber- sumber lain yang relevan dengan masalah penelitian.

\section{Teknis Analisis Data}

$$
\text { dalam penelitian ini }
$$
menggunakan rumus WMS.

$$
\begin{gathered}
I=\frac{\text { Skor Tertinggi }- \text { Skor Terendah }}{\text { Jumlah }} \\
I=\frac{5-1}{5}=0,8
\end{gathered}
$$

Dari ketentuan diatas, maka tingkat kategori jawaban yang diperoleh ditentukan dengan kriteria penafsiran sebagai berikut :

Tabel Skala likert

\begin{aligned} & \hline Skor \multicolumn{1}{c}{ Kriteria } \\ & \hline $4,24-5,00$ Sangat Baik \\ & $3,43-4,23$ Baik \\ & Sedan \\ & $2,62-3,42$ g \\ & $1,81-2,61$ Buruk \\ & $1,00-1,80$ Sangat Buruk \\ & \hline\end{aligned}

Teknik analisa data dalam penelitian ini menggunakan perhitungan Weight means Score (WMS) Menurut Bakri siregar (1981:20) data yang diperoleh dari lapangan lalu diolah berdasarkan jawaban responden melalui angket yang menggunakan rumus WMS :

Keterangan : $\quad M=\frac{\sum(f x)}{n}$

$\mathrm{M}=$ Perolehan angka kriteria penafsiran

$\mathrm{f}=$ Frekuensi jawaban 
$\mathrm{x}=$ Pembobotan (skala nilai)

$\Sigma=$ Penjumlahan

$\mathrm{n}=$ jumlah seluruh jawaban responden

\section{HASIL DAN PEMBAHASAN}

Berdasarkan hasil penelitian, diperoleh bahwa evaluasi program RSPA police goes to school di SMA Negeri 6 dan SMK Pembangunan Kota Bogor memperoleh skor rata - rata sebesar 3,64 yang menurut penafsiran kriteria berada pada kategori baik. Evaluasi program dijelaskan melalui 6 dimensi yaitu efektifitas, efesiensi, kecukupan, pemerataan, responsivitas, dan ketepatan. Berikut rekapitulasi variabel Evaluasi Program RSPA police goes to school:

\section{Tabel}

\section{Rekapitulasi Variabel Evaluasi} Program RSPA Police Goes To School

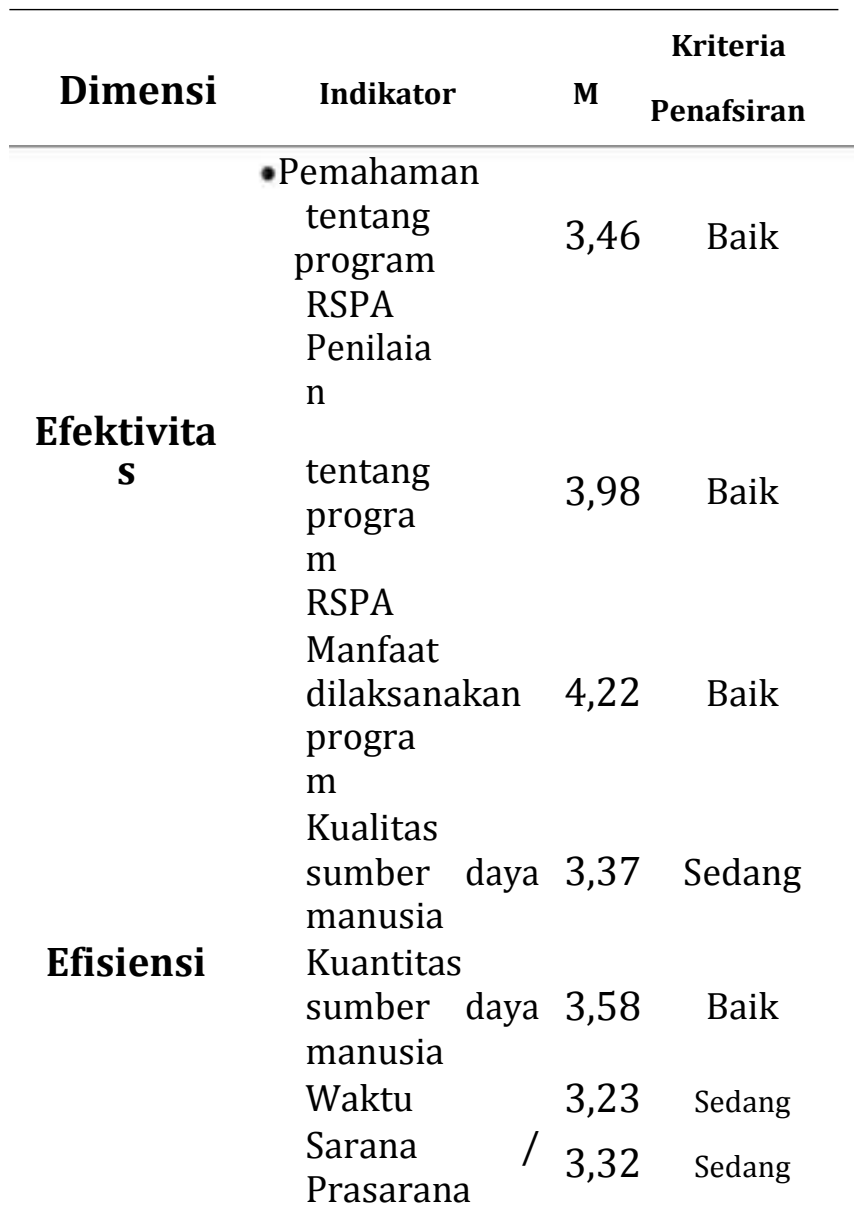

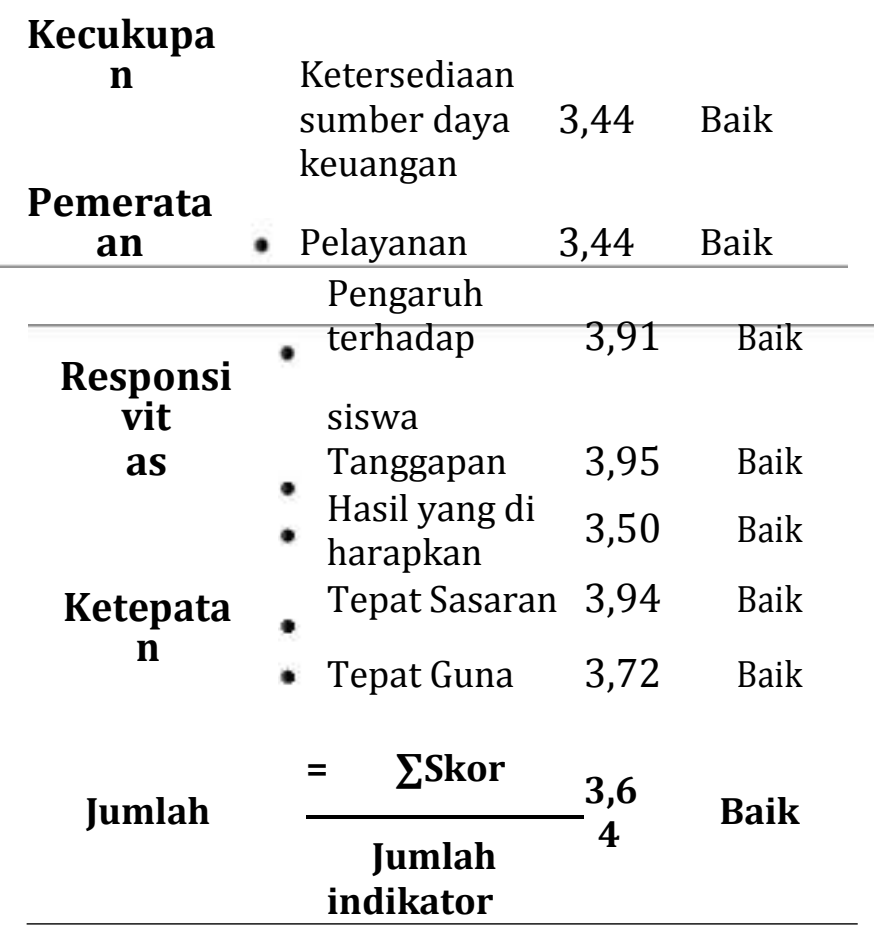

Apabila dirinci menurut dimensi dalam evaluasi program maka dimensi efektifitas merupakan dimensi dengan nilai rata-rata paling besar yaitu 3,88 relatif terhadap dimensi lainnya. Sementara itu dimensi kecukupan secara relative merupakan dimensi dengan nilai yang rendah dengan nilai 3,38 .

\section{Pembahasan}

Dalam pelaksanaan program road safety partnership action police goes to school di SMA Negeri 6 dan SMK Pembangunan Kota Bogor yang dilaksanakan pada tahun 2016 pelaksanaan kegiatan kampanye safety riding berupa penyuluhan kepada para pelajar dikota bogor telah dilaksanakan salah satunya di dua sekolah yaitu SMA Negri 6 dan SMK Pembangunan Kota Bogor. Dalam kegiatan tersebut telah diberikan penyuluhan kepada 300 siswa SMA Negeri 6 dan 200 siswa SMK Pembangunan. Kegiatan penyuluhan tersebut dilaksanakan dalam 3 sesi yaitu : (1) teori cara berkendara dengan selamat (safety riding), (2) demo berkendara dengan menggunakan simulator sepeda motor; (3) praktek 
cara berkendara dengan selamat dan cara mendapatkan sim.

Ternyata setelah diadakannya sosialisasi program RSPA police goes to school, masih ada siswa sekolah baik SMAN 6 maupun SMK Pembangunan Kota bogor yang tidak memiliki kemampuan penguasaan teori dan praktek dengan baik, ditambah dengan kesadaran para pengendara bermotor yang rendah sehingga setiap hari semakin banyak terjadi pelanggaran lalu lintas yang sering menyebabkan kecelakaan lalu lintas yang mengakibatkan kerugian baik materi maupun jiwa manusia itu sendiri. Dan belum memiliki SIM namun mereka tetap mengendarai sepeda motor dan melalui jalan raya tanpa memiliki SIM. Berdasarkan hasil kuisioner yang dilakukan oleh penulis kepada siswa/siswi SMAN 6 dan SMK Pembangunan Kota bogor dengan masing-masing sampel 90 dan totalnya 180 dapat diketahui bahwa siswa yang memiliki SIM dari 180 orang pengendara sepeda motor hanya 13 orang dari kedua sekolah tersebut dan 167 orang melanggar aturan karena mengendarai tanpa memiliki SIM.

Berdasarkan kenyataan tersebut maka tujuan diselenggarakannya progam RSPA police goes to school seperti keamanan, keselamatan, ketertiban dan kelancaran belum tercapai.

Bisa kita lihat jumlah pelanggaran lalu lintas berdasarkan tingkat pendidikan yang dilakukan pelajar pada gambar dibawah ini:

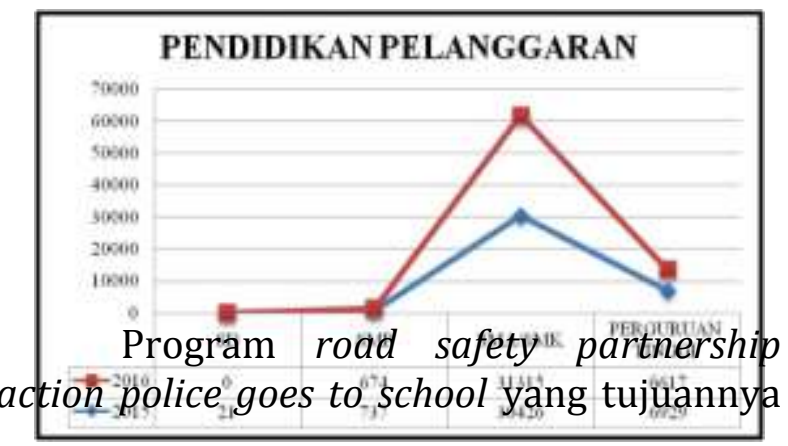

untuk menurunkan angka pelanggaran lalu lintas dan memberikan pemahaman kepada pelajar tentang arti pentingnya keselamatan berlalu lintas ternyata bisa kita lihat dari hasil penelitian Program road safety partnership action police goes to school di SMAN 6 dan SMK Pembangunan kota bogor ini di anggap belum maksimal dalam menurunkan angka pelanggaran lalu lintas dan belum mampu untuk memotivasi pelajar di tingkat SMA / SMK untuk mematuhi aturan hukum yang berlaku. Karena dari hasil penelitian dan didukung oleh data pelanggaran dari satlantas unit tilang polresta bogor selama tahun 2015 dan 2016 kasus angka pelanggaran masih tinggi.

Faktor-faktor terjadinya siswa/siswi melakukan pelanggaran lalu lintas membawa kendaraan sepeda motor kesekolah yang dilakukan oleh siswa/siswi disebabkan faktor internal dan faktor external, dimana faktor internal antara lain: faktor ketidak disiplinan, faktor kealpaan /lupa, faktor ketidak pahaman / ketidaktahuan, dan faktor kelalaian. Sedangkan faktor externalnya diantaranya faktor sarana dan prasarana jalan, faktor orang tua, faktor pergaulan bebas. Akibat fatal yang di sebabkan dari pelanggaran lalu lintas yaitu kecelakaan.

Dalam mengatasi permasalahan tersebut yang terdapat dalam Evaluasi program RSPA police goes to school upaya yang telah dilakukan pelaksana program diantaranya:

1. Metode preventif ini adalah upaya pencegahan yang dilakukan pihak Satlantas Polres bogor yang dilakukan sebelum terjadinya suatu pelanggaran. Bentuk dari metode preventive ini ialah dengan menggelar oprasi/patrol rutin apabila oprasi rutin ini belum mendapatkan hasil yang maksimal maka dilaksanakan oprasi khusus, Cara kerja oprasi khusus ini yaitu dengan yaitu dengan menggelar razia. 
Metode Represif biasanya disertai dengan upaya penerapan paksa. Tindakan represif dilakukan terhadap setiap jenis pelanggaran. Penegakan Bentuk dari metode represif ialah berupa tindakan yang disetai hukuman atau denda contohnya ialah Tilang, apabila tindak pelanggarannya berat sehingga menimbulkan kecelakaan yang disertai korban jiwa maka dapat pula diberikan sanksi berupa kurungan penjara sesuai UU No.22 tahun 2009 tentang lalu lintas dan angkutan jalan.

\section{KESIMPULAN DAN IMPLIKASI}

Berdasarkan hasil analisis penelitian evaluasi program road safety partnership action police goes to school di SMA Negeri 6 dan SMK Pembangunan Kota bogor dapat disimpulkan bahwa :

1. Program road safety partnership action police goes to school di SMAN 6 dan SMK Pembangunan kota bogor ini di anggap belum maksimal dalam menurunkan angka pelanggaran lalu lintas dan belum mampu untuk memotivasi pelajar di tingkat SMA / SMK untuk mematuhi aturan hukum yang berlaku.

2. Faktor penghambat masih banyaknya pelajar yang belum memahami UU No 22 tahun 2009 tentang Lalu Lintas dan Angkutan Jalan dan kurangnya kesadaran dalam berlalu lintas,adanya pembiaran dari pihak orang tua, Adanya persepsi mengenai lemahnya kemampuan hukum, Pelajar (pengendara) tidak pernah merasa jera.

3. Upaya yang dilakukan Satlantas Polres bogor dalam menanggulangi pelanggaran lalu lintas yang disebabkan oleh pengendara sepeda motor ialah dengan cara memberlakukan metode preventif (upaya pencegahan) dan menerapkan metode represif.

\section{Implikasi Teoritis}

Model Evaluasi Program dalam penelitian ini menggunakan teori William
N. Dunn. Oleh karena itu, Hasil penelitian ini berpijak pada teori William N. Dunn yang mempunyai beberapa dimensi diantaranya Efektifitas, Efesiensi, kecukupan, pemerataan, responsivitas, ketepatan, sudah tepat digunakan dalam penelitian evaluasi program road safety partnership action police goes to school di SMA Negeri 6 dan SMK Pembangunan Kota Bogor.

Model evaluasi ini menggunakan tujuan-tujuan tersebut sebagai kriteria untuk menentukan keberhasilan. Model ini dianggap lebih praktis untuk mendesain dan mengembangkan suatu evaluasi program, karena menentukan hasil yang di inginkan. Maka evaluasi program ini akan menjadi lebih praktis.

\section{Implikasi Praktis}

1. Masalah keselamatan transportasi jalan melibatkan beberapa bidang/disiplin (multidisciplinary problem), sehingga perencanaan dan penyelenggaraan program keselamatan hendaknya terintegrasi, terkoordinasi, dan berkelanjutan.

2.Pelaksanaan program aksi keselamatan transportasi jalan yang komprehensif dan berkelanjutan memerlukan biaya yang besar. Efektivitas pelaksanaan program sangat bergantung pada kecukupan dana yang tersedia. Dari pengalaman beberapa negara yang telah melaksanakan program aksi keselamatan transportasi jalan secara berkelanjutan, diperoleh bahwa kebutuhan dana guna pembiayaan program dapat berasal dari beberapa sumber, seperti anggaran pemerintah, pungutan pemakai jalan (impor, pembelian kendaraan, bahan bakar, jalan tol, dan lain-lain), pajak retribusi sumber-sumber lalulintas (pajak kendaraan, pajak pembelian kendaraan, pajak bahan bakar, dan lain-lain), kontribusi pihak swasta 
(sponsor agen penjualan kendaraan, perusahaan minyak, perusahaan angkutan, dan lain-lain), asuransi kendaraan bermotor, serta denda pelanggaran.

Untuk kota bogor dapat dibuat kebijakan serupa, dan tentunya akan menghasilkan dana yang sangat besar untuk program keselamatan. Skenario alokasi dana dapat dilakukan secara proporsional sesuai dengan banyaknya kendaraan di setiap provinsi, kabupaten, dan kota, karena setiap wilayah memiliki tingkat kesulitan pelaksanaan program yang berbeda sesuai karakteristik masing-masing.

\section{DAFTAR PUSTAKA}

\section{Sumber Undang-Undang :}

UNDANG - UNDANG RI Nomor 22 Tahun 2009 Tentang Lalu Lintas Dan Angkutan Jalan

\section{Sumber Buku :}

Dunn, William N.2003 Pengantar analisis kebijakan Publik : edisi kedua. Yogyakarta : Gajah Mada University

Handoko, Hani. 1989. Manajemen Edisi Kedua. Yogyakarta : PT.BPFE Yogyakarta.

IG.Wursanto, 1983. Dasar-dasar manajemen umum, Jakarta : PUSTAKA DIAN

Nugroho. D Riant, 2003. Kebijakan Publik Formulasi, Implementasi Dan Evaluasi, Jakarta : PT Elex Media Komputindo.

Sukandarrumidi, Dwiyanto, 2009 metodologi penelitian: cetakan keempat, Yogyakarta gajah mada university press

Suprapto.Agus 2015, Profil \& Direktori Dinas Lalu Lintas dan Angkutan Jalan Kota Bogor. Penerbit: DLLAJ Kota Bogor

Sugiyono, 2003. Metode Penelitian Administrasi, bandung : Alfabeta.
World Health Organization 2006 Helmets : a road safety manual for decision-makers and practitioners Global Road Safety Partnership - Indonesia

Wibawa,Samodra, 1994. Kebijakan Public Proses Dan Analisis, Jakarta : Intermedia

\section{Sumber Skripsi :}

Cynthia Utari, Gineung. 2010. Hubungan Pengetahuan, Sikap, Persepsi, Dan Keterampilan Mengendara Mahasiswa Terhadap Perilaku Keselamatan Berkendara (Safety Riding). Jurusan Kesehatan Masyarakat. Fakultas Kedokteran Dan Ilmu Kesehatan. Universitas Islam Negeri Syarif Hidayatullah Jakarta.

Wiyono Sugeng , 2013. Kajian Pelaksanaan Rspa (Road Safety Partnership Action), Di Provinsi Riau Tahun 2012. Jurusan Teknik Sipil, Universitas Islam Riau.

\section{Sumber Jurnal :}

Jurnal Pendidikan Kewarganegaraan Pemahaman Norma Berlalu Lintas Pada Siswa Sman 7dan Smkn 5 Banjarmasin Zainul Akhyar, Harpani Matnuh, AzrianoorProgram Studi PPKn FKIP Universitas Lambung Mangkurat

Permana, Bambang Eka. 2012. "Faktor Penyebab Pelanggaran Lalu lintas Oleh Pengendara Sepeda Motor Di Kota Kuningan". Jurusan politik Dan Kewarganegaraan. Fakultas Ilmu Sosial. Universitas Negeri Semarang.

Putu Wily, Oki Pratiwi. 2014. Pelanggaran Lalu Lintas Kendaraan Bermotor Roda Dua Yang Dilakukan Oleh Siswa Sekolah Menengah Pertama (Studi Kasus Pada Wilayah Polres 
Kabupaten Tabanan, Dikota Tabanan). Jurusan Pendidikan Pancasila Dan Kewarganegaraan. Fakultas Ilmu Sosial. Universitas Pendidikan Ganesha.

Rakhman, Feti. 2013. Kepatuhan Remaja Dalam Berlalu Lintas. Jurusan Ilmu Sosiatri. Fakultas ilmu sosial dan ilmu politik. Universitas Tanjung Pura Pontianak.

Sulistio, Harnen. 2008. Keselamatan Transportasi Jalan Di Indonesia Saatnya Ada Perubahan. Jurusan Teknik Sipil. Universitas Brawijaya Malang. 